\section{Nuclear technology transfer}

\section{Troubles for US-China pact?}

Washington

THE transfer of nuclear technologies from the United States to China would provide short-term benefits but could pose risks to the United States by the end of the century if relations between the two countries were to deteriorate, according to a technical memorandum issued last week by the Office of Technology Assessment (OTA)* . The report was part of the evidence presented at a congressional hearing on the US nuclear energy cooperation agreement with China, which establishes a basis for cooperation between the United States and China in peaceful applications of nuclear energy; it is not a commitment to supply technology and expertise.

Increased trade, improved relations between the two countries and increased world energy supplies are the immediate benefits of technology transfer, OTA says. Exports to China could be worth several thousand million dollars in the next decade. OTA thinks it únlikely that China will find US reactor technology useful in nuclear weapons programmes, but expresses concern about China reexporting to other countries and the disposition of spent fuel. Declarations by China's leaders that they will not assist others to develop nuclear weapons lack the force of a written treaty. But Ambassador Richard T. Kennedy, US negotiator of the agreement, said last week that China has made "significant new statements of its non-proliferation policy" and that he is satisfied that these policies are "consistent with our own basic views".

OTA warns, however, that China's nuclear submarines could benefit from "exposure to sophisticated nuclear industrial practices" in making possible quieter, more reliable and more powerful vessels. But the effects of a pact would be limited, says OTA, as China already has the reprocessing and enrichment technology that could create proliferation dangers and is importing from other countries the expertise that could be useful in improving weapons. Most energy technologies have no direct military applications, and the US-China pact expressly excludes the transfer of enrichment and reprocessing.

OTA was asked to produce the report by the Senate Banking Committee and a subcommittee of the House Energy and Commerce Committee. Senator Jake Garn (Republican, Utah), chairman of the former, strongly criticized the report for concentrating on the benefits to China and ignoring questions such as the future impact of technology transfer on US security and the effects of a strong China on countries in the region allied to the United States. Representative Ed Markey (Democrat, Massachusetts), a member of the House of Representatives' committee, questions whether the agreement will be

\section{Poland}

of significant value for US trade because of competition with French, German, British and Japanese companies already bidding for existing contracts, and because China is likely to become self-reliant in nuclear technologies very quickly. Markey criticized the vagueness of the agreement over the exchange of information and US visits to nuclear facilities in China.

Markey is attempting to show that the agreement violates the Nuclear NonProliferation Act of 1978 but it is unlikely that he will be able to stop Congress ratify-

ing the pact. If he proves he is right, President Reagan must resubmit the agreement to Congress with a waiver for those parts of it that do not meet statutory requirements. Congress would then have to approve of the pact by a joint resolution, which would give it special status. Other countries with technology transfer agreements with the United States would not then be able to use the US-China pact as a precedent for renegotiation. More probably, Markey's bid will fail and the pact will be ratified by default 90 days after its introduction by the President to Congress, February next. Maxine Clarke

*Energy Technology Transfer to China. US Governmen Printing Office, Washington. DC 20402: \$4.50.

\title{
Government denies pollution
}

ClaIMs that Poland is "the most ecologically threatened country in Europe" were denied last week by the Polish government press spokesman, Mr Jerzy Urban. The disputed report, he said, which was produced by the Polish Academy of Sciences' Committee on the Chemical Sciences is "not official", and its "alarmist and exaggerated" formulations are merely the views of "individual contributors".

Urban's criticism was ostensibly aimed, not at the report itself, but at an article based on it, which appeared in the daily Zyccie Warszawy (Warsaw Life) on 30 August. Refuting the article during his regular Tuesday press conference with foreign journalists, Urban claimed that Poland had "threatened areas", but no "areas of ecological disaster". Moreover, he said, the report did not reflect the government's commitment to the protection of the environment. The data used, he alleged, derived from the 1970 s and even earlier.

In fact, the data of the academy's report cover the period up to the end of 1983. In a bold and, for present-day Poland, unusual move, the editors of Zyccie Warsawy next day published a leading article saying that although the government spokesman had access to more data than did its journalists (an allusion to the tacit reimposition of censorship in matters relating to the environment), a report presented to the Sejm (Parliament) in June by the head of the government's Office for Environmental Protection had "presented the current situation without beating around the bush and without concealing the serious dangers prevalent in certain areas".

The dismissal of the academy report as merely the views of certain individuals inevitably raises doubts as to the Polish government's willingness to listen to experts whose message fails to accord with the government viewpoint. In fact the academy document follows closely that of the report to the Sejm, even to the definition of 23 ecological "disaster areas". Other points raised by the academy include:
- A "shocking" increase in the number of retarded children in Upper Silesia, due to the increased concentration of heavy metals, particularly lead, in the environment. - Air pollution in Poland is now the worst in Europe; of 1,066 factories whose emissions have been classified as environmentally harmful, only half have fixed maximum emission levels while 304 of the worst emitters have no set limits at all.

- The volume of automobile exhaust fumes is disproportionately high compared to the number of vehicles and, in spite of the severe fuel shortage, Polish vehicles burn twice as much fuel per kilometre as the world average.

- Poland has the highest proportion of smokers in the world, and the cigarette quality is particularly low, so that tobacco is a major source of indoor pollution.

- Of the 4,700 million $\mathrm{m}^{3}$ per year of waste water requiring treatment, almost half is discharged into rivers, lakes and the sea without treatment and another 30 per cent receives only mechanical treatment. More than 50 per cent of Polish cities, including Warsaw, have no sewage works. Seepage from urban and industrial effluent and the excessive use of fertilizers has led to massive degradation of ground waters.

The academy's report also claims that food crops are heavily polluted by industrial emissions. Close to urban industrial complexes, the concentration of cadmium is as much as 220 times the natural level; near the Boleskaw and Miastecsko Slaskie metallurgical works, the concentration of lead in market garden produce reached $230 \mathrm{mg}$ per kilo (the maximum permissible dose is $3 \mathrm{mg}$ per person per week).

According to Zyccie Warsawy, the team who prepared the report did so "to represent the strategic problems and suggest necessary action... with a measure of faith in its usefulness, despite the fact that examples from the recent past do not warrant such optimism". Mr Urban's unequivocal rejection of their report suggests, alas, that such "optimism" is still unjustified.

Vera Rich 